\title{
Corrigendum: TCR $\alpha$-TCR $\beta$ pairing controls recognition of CD1d and directs the development of adipose NKT cells
}

Joshua A Vieth, Joy Das, Fanomezana M Ranaivoson, Davide Comoletti, Lisa K Denzin \& Derek B Sant'Angelo

Nat. Immunol. 18, 36-44 (2017); published online 21 November 2017; corrected after print 17 April 2017

In the version of this article initially published, the symbols in the key for Figure $5 \mathrm{f}$ were identified incorrectly. The correct key is open circle for $\mathrm{V}_{\beta} 8.2(\mathrm{~F} 108 \mathrm{Y})$ and red square for $\mathrm{V}_{\beta} 8.2(\mathrm{WT})$. The error has been corrected in the HTML and PDF versions of the article.

\section{Corrigendum: Spontaneous partial loss of the OT-I transgene}

Gretchen Harms Pritchard, Eric W Cross, Marjorie Strobel, Stephen C Jameson, Ross M Kedl, Kristin A Hogquist \& Christopher A Hunter Nat. Immunol. 17, 471 (2016); published online 19 April 2016; corrected after print 18 May 2017

In the version of this Correspondence initially published online, the following two relevant references were not included: Sporri, R. \& Reis e Sousa, C. Eur. J. Immunol. 32, 3161-3170 (2002); and Montaudouin, C. et al. PLoS One 5, e10238 (2010). They have now been included, along with text explaining their relevance. The error has been corrected in the PDF and HTML versions of this article.

\section{Erratum: Gut microbial metabolites limit the frequency of autoimmune T cells and protect against type 1 diabetes}

Eliana Mariño, James L Richards, Keiran H McLeod, Dragana Stanley, Yu Anne Yap, Jacinta Knight, Craig McKenzie, Jan Kranich, Ana Carolina Oliveira, Fernando J Rossello, Balasubramanian Krishnamurthy, Christian M Nefzger, Laurence Macia, Alison Thorburn, Alan G Baxter, Grant Morahan, Lee H Wong, Jose M Polo, Robert J Moore, Trevor J Lockett, Julie M Clarke, David L Topping, Leonard C Harrison \& Charles R Mackay Nat. Immunol.; doi:10.1038/ni.3713; corrected online 5 April 2017

In the version of this article initially published online, the callout for Figure $4 \mathrm{~g}$ was incorrectly attributed, and Figure 5d was displayed incorrectly. The errors have been corrected in the print, PDF and HTML versions of the article.

\section{Erratum: Ontogeny and homeostasis of CNS myeloid cells}

Marco Prinz, Daniel Erny \& Nora Hagemeyer

Nat. Immunol. 18, 385-392 (2017); published online 22 March 2017; corrected after print 26 April 2017

In the version of this article initially published, some of the arrows along the right side of Figure 1 were incorrect. The arrow from 'Ly6 $\mathrm{C}^{\text {hi }}$ monocyte' to 'pvMФ long-living' should be deleted, and an arrow should be added from 'Ly6C hi monocyte' into the boxed area above (top right). The error has been corrected in the HTML and PDF versions of the article.

Erratum: NLRP12 attenuates colon inflammation by maintaining colonic microbial diversity and promoting protective commensal bacterial growth

Liang Chen, Justin E Wilson, Mark J Koenigsknecht, Wei-Chun Chou, Stephanie A Montgomery, Agnieszka D Truax, W June Brickey, Christopher D Packey, Nitsan Maharshak, Glenn K Matsushima, Scott E Plevy, Vincent B Young, R Balfour Sartor \& Jenny P-Y Ting Nat. Immunol. 18, 541-551 (2017); published online 13 March 2017; corrected after print 17 April 2017

In the version of this article initially published, the second sentence in the first subsection of Results incorrectly described an experimental group as “... seven additional patients with UC...”. The correct description is “...seven additional UC patient cohorts...”. The error has been corrected in the HTML and PDF versions of the article. 